\title{
Exploring the Information Literacy Skills Among Minangkabau Community in Agam District, Indonesia
}

\author{
Elva Rahmah ${ }^{1, *}$ Shamila Mohammed Shuhidan ${ }^{2}$, Wan Aida Wan Yahaya ${ }^{3}$ \\ ${ }^{1}$ Indonesian Language and Literature Department, Universitas Negeri Padang, Padang, Indonesia \\ ${ }^{12}$ Faculty of Information Management, Universiti Teknologi MARA, Selangor, Malaysia \\ ${ }^{3}$ Faculty of Film, Universiti Teknologi MARA, Selangor, Malaysia \\ "Corresponding author. Email: elva@fbs.unp.ac.id
}

\begin{abstract}
The purpose of this study was to examine the level of skill information literacy, of the Minangkabau community in Agam district, Indonesia. The trial was conducted to test the reliability and validity of the measuring instrument. The pilot study was conducted in 30 Minangkabau communities from the Agam district. In this way, the researchers distributed the instrument among 30 participants (male, $n=11$; female, $n=19$ ), and their responses were recorded. This study uses quantitative methods. The findings showed that first, the investigation of the Minangkabau Community information literacy level of skills was shown as follows (a) most of the respondents knew the required information $17(56.7 \%)$, were able to define 17 (56.7\%) and evaluated the required information 18 (60\%); (b) most of the respondents do not understand the information search strategy, this can be seen from the respondents who disagreed with my statement in determining the source of the information I was looking for related to the topic sought $19(63.3 \%)$; (c) most respondents do not understand the location and access to information, this can be seen from the statement that most respondents disagree with my statement in determining the steps used to find the information I need $14(46 \%)$; (d) most respondents use information to solve problems $16(53.3 \%)$; (e) related to organizing information, most respondents grouped information according to information subject 16 (53.3\%) and could find information that had been stored easily and quickly $15(50 \%)$, and (f) most respondents evaluated various information found $16(53.3 \%)$. Second, the status of local wisdom of the Minangkabau community can be seen from (a) socialization, most respondents agree with the statement of social relations related to ancestral culture $20(66.67 \%)$; (b) externalization, most respondents agree with the statement that the documentation of Minangkabau local wisdom is a cultural heritage that exists in the community which is carried out for generations by the community concerned; (c) the combination, most of the respondents disagree with the statement get used to learning from reading books, news, and documents indigenous knowledge 16 (53.3); and (d) internalization, most of the respondents disagree with the statement manage indigenous knowledge training program $16(53.3 \%)$.
\end{abstract}

Keywords: information literacy, information literacy skills, culture of literacy, indigenous knowledge, Minangkabau community

\section{INTRODUCTION}

Habituation that appears in individual groups collectively will bring up a literacy culture that becomes the identity of a community group. A literate and highly civilized society characterizes a great country. A nation's culture typically goes hand in hand with the culture of literacy, cultural influences, and society affected by reading from the findings of scholars immortalized in literature, which makes the legacy of knowledge literacy very useful for processes of dynamic social life. In this case, literacy is not only a matter of how a country is free from illiteracy, but how individuals have the potential to create wealth in their lives. Literacy means information, language, and culture-related activities, and social relationships. The Minangkabau tradition is one of these cultures. Based on this, the ability to extract information embedded in various cultural elements requires information literacy, especially cultural literacy. As a framework for the introduction of culture and the cultural learning process to society, the creation of cultural literacy is required. Through the advancement of cultural literacy, the next generation will be developed by national cultural values, with souls and characters. 


\section{BACKGROUND}

Literacy can be defined as the capacity to read and write when talking about literacy in basic terms. The culture of literacy or the culture of reading and writing, especially those living in rural areas, including those living in Agam Regency, West Sumatra, Indonesia, does not appear to have developed in society yet. Illiteracy data for the Agam district was 0.65 percent (male $0.28 \%$ and female $0.37 \%$ ) in 2019, based on data from the West Sumatra Province Central Statistics Agency. It is also hoped that culture will continue to change the lives of people. Cultural possession, both socially, politically, and economically. If the process of transmitting cultural knowledge can be carried sustainably, a society that is literate in cultural knowledge can be created, and a society that is literate in cultural information can also be built.

Factors of Influence on sharing of cultural heritage knowledge have included rewards, expect a relationship, enjoy helping, self-efficacy, reciprocity, and intention to share. A reward is the main factor that influences individuals to share cultural heritage knowledge [1]. Literacy initially had a basic reach, but now it has expanded. Literacy originally meant just literacy, indicating that it was possible for those who were literate to read. Then, in a specific area, the notion of literacy translates into knowledge and skills. Literacy is also understood as a pattern of social interaction related to knowledge, social, and culture (UNESCO, 2003) [2]. So that its existence is always related to human life in society. Therefore, literacy is very important in life. Without literacy skills, one cannot participate in society. Patah (2014) explained that information literacy skills create skill-based literacy which includes the skills of searching, sorting, using, and presenting ethically [3]. Due to rapid technological, social, cultural, and economic change, deliberate lifelong learning, either formally or self-managed, is seen as necessary [4]. The transforming process of information literacy is at the heart of lifelong learning and empowers individuals in all walks of life to efficiently access, analyze, use and produce information to achieve their personal, social, occupational, and educational objectives [5]. It is a basic human right in a digital world and promotes the social inclusion of all nations [6].

Lupton (2004) noted at least three ways to view the relationship between information literacy, information seeking and use, and information behavior. These include (1) IL is parallel to the behavior of information seeking and use; (2) IL intersects with the behavior of data seeking and use; and (3) IL subsumes the behavior of information seeking and use [7].

In the process of personal change in new intercultural environments, information literacy activities play a key role. Meanwhile, in today's multicultural society, the ability to adapt to new cultural contexts is increasingly necessary. Multicultural literacy has to be mentioned as a new concept. It is the capacity to identify, compare, contrast, and appreciate commonalities and differences in beliefs and values of cultural practices within and between cultures [8].

The evolution and course of the community information literacy research agenda are influenced by Bruce (2000) and the Prague Meeting of Experts (Thompson \& Cody 2003). They note that more work is required to look at (1) the essence of awareness, information, and information literacy (IL) in different cultures, (2) person and community IL experiences, (3) what motivates people to walk the IL route, (4) methods to help individuals and groups become IL, (5) people's IL experiences in public and proprietary information environments, (6) different experiences of information literacy in rural and urban communities, (7) experience of information literacy in oral learning communities to allow digital information literacy skills to be developed, (8) experience of information literacy in digital environments, (9) and experience of information literacy in different contexts in the community [7].

Literacy is a mirror of a society that can be considered civilized humans by literary humans. It is possible to use literacy programs as a way of disseminating culture. Not only reading and writing but also cultural literacy should be associated with literacy. To reinforce and conserve Indonesian culture, the younger generation must recognize and preserve their own regional culture. Preserving national standards is an attempt to uphold traditional values. Cultural preservation aims to reinforce cultural values within the world.

While most people have for a long time overlooked indigenous awareness of the citizens of Minangkabau, it has been practiced for decades and still survives to this day. Heritage is all that belongs to a people's distinct and is theirs to share, with other people. It contains all the items deemed by international law to be the artistic output of human thinking and craftsmanship, such as compositions, tales, science expertise, and works of art [9]. Cultural heritage is the legacy of the physical objects and intangible qualities of a culture or society, which are inherited from the past and preserved for the benefit of future generations in the present [10].

In the community-based information repository that maintains the culture, the rules of community life are preserved in the form of tacit knowledge. The process of inheriting local knowledge is not an easy thing like the inheritance of tangible objects (tangible heritage). That means the process of inheriting local knowledge in the form of tacit is not fully or $100 \%$ transferred to the heir of knowledge because many factors that influence the knowledge cannot be $100 \%$ interpreted by the heirs of knowledge. Indigenous communities around the world face ongoing threats to the survival of their indigenous knowledge given its tacit nature [11]. 
Local institutions are also generally unknown for the transfer of individual knowledge activities and are not yet a program activity for literacy movement by literacy activists and cultural empowerers. This is important to monitor the relevant knowledge streams. As a way of linking the past, current, and future generations. Local knowledge erosion in a community is a community phenomenon.

The lack of effort to outsource information in society's failure in enforcing secret technology transfer (tacit awareness) is held solely by those individuals. There is also a lot of understanding for the Minangkabau citizens in externalizing cultural information. There is no doubt therefore that it is difficult for the Minangkabau community to find literature or references related to the Minangkabau culture. The preservation of information is carried out by deciding who holds the knowledge, the knowledge to be protected, and who will conserve the knowledge. It is clear that if IK is not registered and retained, it will be lost and will remain unavailable to other indigenous systems as well as to development staff.

Indonesia is a rich spot for cultural awareness with an inhabitant community of over 300 ethnic groups. It is not shocking, therefore to know that Indonesia has the immense potential of indigenous knowledge. Indonesia, though, also has several things to address in the legal system [12]. Indigenous peoples have the right to protect their intellectual property from unauthorized and excessive usage, including the right to protect their owners [13]. Two national laws act as the legal basis for the traditional process of documenting knowledge. There are Copyrights Law No. 28 of 2014, Patent Law No. 13 of 2016, and Cultural Advancement Law No. 5 of 2017. The basic subject of conventional information reporting is, to be exact, in Article 38 of Copyright Law 2014 No. 28 [12].

Article 38 of Law No 28 of 2014 on copyright states that the State owns the copyright in respect of traditional cultural expressions. Folklore, folklore, legends, historical narratives, compositions, songs, handicrafts, choreography, dances, and calligraphy are examples of those works. However, in any implementation case, Article 38 does not affect abroad because it has been governed by the laws of the country concerned about intellectual property rights (IPR). Domestically, Article 38's obscurity invites legislation to be expanded, in particular on inherently controversial concepts such as artistic "authenticity" [13].

The protection provided by the current IPR legislation is felt to be very individual, not yet in a position to provide adequate protection against the ownership of traditional technological knowledge, which is generally owned by groups within society. The reality of their diversity is the most important aspect that must be known and realized in understanding the problems faced by indigenous peoples. The protection of indigenous knowledge must be placed on the development of legislation which includes the planning, training, and renewal of national law ideally implemented with a system-oriented approach. From the Intellectual Property Rights perspective, traditional knowledge is one property that is difficult to protect due to its distinct and unique features.

\section{METHOD}

The pilot testing was performed to test the reliability and validity of the measuring instruments. the pilot study was conducted in 30 Minangkabau communities from Agam districts. In this way, the researchers distributed the instruments among 30 participants (males, $\mathrm{n}=11$; females, $\mathrm{n}=19$ ), and their responses were recorded. This investigation used quantitative methods. Whereas quantitative data usually involve closed responses, such as those found on questionnaire tools [14]. In this analysis, purposeful random sampling was used since there is a known possibility of the elements in the population being chosen as sample subjects. Simple random sampling is the sampling tool for this analysis. With a view to the degree of literacy among the Minangkabau population and the status of indigenous knowledge. A comprehensive analysis was carried out using a voluntary sample survey of the population of the Agam Community of West Sumatera in Indonesia.

\section{RESULT AND DISCUSSION}

The investigation was carried out by the level of skill information literacy, and the status of indigenous knowledge of the Minangkabau Community in Agam District, Indonesia.

\subsection{Participants' Demographic Characteristics}

To conduct this cross-sectional study successfully, 30 participants joined after getting their permission. The demographic characteristics of the participants were analyzed basis on a simple percentage.

Table 1. Participants demographic characteristics

\begin{tabular}{llr}
\hline Characteristics & \multicolumn{1}{c}{ Categories } & \multicolumn{1}{c}{$\mathbf{N}(\boldsymbol{\%})$} \\
\hline District & Lubuak Basung & $1(3.3 \%)$ \\
& IV Koto & $1(3.3 \%)$ \\
& Banuhampu & $23(76.7 \%)$ \\
& IV Angkek & $2(6.7 \%)$ \\
& Candung & $1(3.3 \%)$ \\
& Baso & $2(6.7 \%)$ \\
Age (in years) & $16-20$ & $2(6.7 \%)$ \\
& $21-25$ & $10(33.3 \%)$ \\
& $26-30$ & $8(26.7 \%)$ \\
& $31-35$ & $4(13.3 \%)$ \\
& $36-40$ & $0(0 \%)$ \\
& $41-45$ & $3(10 \%)$
\end{tabular}




\begin{tabular}{llr} 
& $46-50$ & $1(3.3 \%)$ \\
Gender & 50 and above & $2(6.7 \%)$ \\
& Male & $11(36.7 \%)$ \\
Academic & Female & $19(63.3 \%)$ \\
Qualification & Junior High School & $2(6.7 \%)$ \\
& High School & $13(43.3 \%$ \\
& Diploma & $5(16.7 \%)$ \\
& Bachelor & $9(30 \%)$ \\
Professional & Postgraduate & $1(3.3 \%)$ \\
Qualification & Farmer & $1(3.3 \%)$ \\
& Laborer & $1(3.3 \%)$ \\
& Traders & $2(6.7 \%)$ \\
& Civil Servants & $2(6.7 \%)$ \\
& Private employees & $7(23.3 \%)$ \\
& Housewife & $5(16.7 \%)$ \\
& Student & $10(33.3 \%)$ \\
& Others & $2(6.7 \%)$ \\
\hline
\end{tabular}

Table 1 portrays that among the district participants, Lubuak Basung 3.3\%, IV Koto 3.3\%, Banuhampu 76.7\%, IV Angkek 6.7\%, Candung 3.3\%, and Baso $6.7 \%$. Regarding the age, only $6.7 \%$ of the participants were in the age group 16-20 years, 33.3\% were grouped in $21-25$ years, $26.7 \%$ were grouped in $26-30$ years, $13.3 \%$ were grouped in $31-35$ years, $10 \%$ were grouped in $41-45$ years, $3.3 \%$ were grouped in $46-$ 50 years and a high proportion of the participants $6.7 \%$ were found having age 50 years and above. $36.7 \%$ were males, and $63.3 \%$ were females. Regarding academic qualification, $6.7 \%$ of participants were junior high school, $43.3 \%$ were high school, $16.7 \%$ were diploma, $30 \%$ were bachelor and $3,3 \%$ were postgraduate. Regarding professional qualification, $3.3 \%$ of the participants were farmers, $3.3 \%$ were laborers, $6.7 \%$ were traders, $6.7 \%$ were civil servants, $23.3 \%$ were private employees, $16.7 \%$ were housewives, $33.3 \%$ were a student and $6,7 \%$ were others.

\subsection{Sources of Information}

Frequency and percentage of participants' sources of information questionnaire Minangkabau community $(n=30)$.

Table 2. Information source category

\begin{tabular}{llr}
\hline \multicolumn{1}{c}{ Question } & \multicolumn{1}{c}{ Categories } & N (\%) \\
\hline $\begin{array}{l}\text { Access } \\
\text { information }\end{array}$ & $\begin{array}{l}\text { Everyday access } \\
\text { information } \\
\text { Two or three times a } \\
\text { week to access }\end{array}$ & $3(10 \%)$ \\
& $\begin{array}{l}\text { information } \\
\text { Once a week to }\end{array}$ & $2(6.7 \%)$ \\
& $\begin{array}{l}\text { access information } \\
\text { Others, please } \\
\text { specify }\end{array}$ & $1(3.3 \%)$ \\
$\begin{array}{l}\text { Type of } \\
\text { printed }\end{array}$ & $\begin{array}{l}\text { Book } \\
\text { Newspaper }\end{array}$ & $14(46.7 \%)$ \\
& & $12(40 \%)$
\end{tabular}

information
media
Types of
electronic
information
media

Bulletin

Magazine

Others

$2(6.7 \%)$

$1(3.3 \%)$

$1(3.3 \%)$

Television

Radio

$7(23.3 \%)$

$1(3.3 \%)$

$0(0 \%)$

Website

$0(0 \%)$

Online newspaper

Social Media

$22(73.3 \%)$

Library

Community Reading

$2(6.7 \%)$

$0(0 \%)$

Gardens

Bookstore

Internet

Family

Information Expert

Traditional

Leaders

Religious Leaders

Community Leaders

$1(3.3 \%)$

$24(80 \%)$

$2(6.7 \%)$

$0(0 \%)$

$1(3.3 \%)$

$0(0 \%)$

$0(0 \%)$

Reason chose the source of the

The resulting

$4(13.3 \%)$

information complete, detailed, and clear

Easy to reach

Is a trusted source

Submission of

information using

language that is

Information easier to understand

form

Print information

Electronic

information

Information

conveyed in person

$20(66.7 \%)$

$2(6.7 \%)$

$4(13.3 \%)$

$2(6.7 \%)$

$20(66.7 \%)$

$8(26,7 \%)$

Prefer printed information

Does not require special skills to access it

The language is easier to understand

Prefer

It's easier to get

$4(13.3 \%)$

electronic

It's easier to access

$23(76.7 \%)$

$2(6.7 \%)$

The language is

easier to understand

It's easier to get

Information

Information relating

do usually ask to livelihoods. For directly

example, how to grow crops, raise livestock, crafts, and others

Information relating

$4(13.3 \%)$

to customs

Information related

to religion 
Others, please specify

Table 2 describes related to the source of information starting from how often respondents access information, most of them access information every day $24(80 \%)$. The type of printed information media that is often used to meet information needs is book 14 $(46.7 \%)$. While the type of electronic information media that is often used to meet information needs is social media $22(73.3 \%)$. About the source of information intended to obtain information, most respondents said the internet 24 (80\%). Meanwhile, the reason respondents chose the information source was mostly easy to reach $20(66.7 \%)$. Most of the respondents fulfill their information needs in the form of electronic information $20(66.7 \%)$. Meanwhile, the reason most respondents like printed information is that it does not require special skills to access it $20(66.7 \%)$. the reason most respondents like electronic information is that it is easier to access $23(76.7 \%)$. To the majority of respondents $19(63.3 \%)$ like information that is conveyed directly because the method of delivery is easier to understand. Information that is usually asked directly, most of the respondents $16(53.3 \%)$ answered Information related to livelihoods.

\subsection{Information Literacy}

Information literacy is defined as a person's ability to obtain the necessary information by recognizing information needs, seeking information, knowing how to obtain information, evaluating information, organizing information, and using the information in the learning process, problem-solving, and making formal and informal decisions in the context of learning, work, home, and education. To find out related to information literacy of the Minangkabau community, it can be seen from the ability to define problems and the identity of information needs, information search strategies, location and access to information, use of information, synthesis, and evaluation.

\subsubsection{Defining the Problem and Identity of Information Needs}

Table 3. Identity of information needs

\begin{tabular}{|c|c|c|c|c|c|}
\hline Question & 1 & 2 & 3 & 4 & 5 \\
\hline $\begin{array}{l}\text { I know the } \\
\text { information I need }\end{array}$ & $\begin{array}{c}17 \\
56.7 \%\end{array}$ & $\begin{array}{c}12 \\
40 \%\end{array}$ & $\begin{array}{c}1 \\
3.3 \%\end{array}$ & $\begin{array}{c}0 \\
0 \%\end{array}$ & $\begin{array}{c}0 \\
0 \%\end{array}$ \\
\hline $\begin{array}{l}\text { I define the } \\
\text { information I need }\end{array}$ & $\begin{array}{c}17 \\
56.7 \%\end{array}$ & $\begin{array}{c}13 \\
43.3 \%\end{array}$ & $\begin{array}{c}0 \\
0 \%\end{array}$ & $\begin{array}{c}0 \\
0 \%\end{array}$ & $\begin{array}{c}0 \\
0 \%\end{array}$ \\
\hline $\begin{array}{l}\text { I formulate in } \\
\text { advance the } \\
\text { information I need }\end{array}$ & $\begin{array}{c}9 \\
30 \%\end{array}$ & $\begin{array}{c}14 \\
46.7 \%\end{array}$ & $\begin{array}{c}7 \\
23.3 \\
\%\end{array}$ & $\begin{array}{c}0 \\
0 \%\end{array}$ & $\begin{array}{c}0 \\
0 \%\end{array}$ \\
\hline $\begin{array}{l}\text { I am re-evaluating } \\
\text { the type of } \\
\text { information needed }\end{array}$ & $\begin{array}{c}18 \\
60 \%\end{array}$ & $\begin{array}{c}11 \\
36.7 \%\end{array}$ & $\begin{array}{c}1 \\
3.3 \%\end{array}$ & $\begin{array}{c}0 \\
0 \%\end{array}$ & $\begin{array}{c}0 \\
0 \%\end{array}$ \\
\hline
\end{tabular}

Strongly Agree $=1$, Somewhat Agree $=2$, Somewhat Disagree $=3$, Disagree a Great Deal $=4$, Don't Know $=5$

Table 3 describes related most of the respondents agreed that I knew what information I needed 17 (567\%), I was able to define the information needed 17 $(56.7 \%)$ and I re-evaluated the type of information needed $18(60 \%)$. In connection with me formulating in advance the information needed, most of the respondents said they did not agree 14 (46\%). The majority of respondents $14(46.7 \%)$ disagree about formulating in advance the information I need.

\subsubsection{Information Seeking Strategies}

Table 4. Information seeking strategies

\begin{tabular}{|c|c|c|c|c|c|}
\hline Question & 1 & 2 & 3 & 4 & 5 \\
\hline $\begin{array}{l}\text { I determine the source } \\
\text { of the information I } \\
\text { am looking for related } \\
\text { to the topic I am } \\
\text { looking for } \\
\text { I use internet sources } \\
\text { to find information }\end{array}$ & $\begin{array}{c}13 \\
43.3 \%\end{array}$ & $\begin{array}{c}16 \\
53.3 \%\end{array}$ & $\begin{array}{c}0 \\
0 \%\end{array}$ & $\begin{array}{c}0 \\
0 \%\end{array}$ & $\begin{array}{c}0 \\
0 \%\end{array}$ \\
\hline $\begin{array}{l}\text { I use to print and } \\
\text { digital media from } \\
\text { various } \\
\text { sources }\end{array}$ & $\begin{array}{c}12 \\
40 \%\end{array}$ & $\begin{array}{c}18 \\
60 \%\end{array}$ & $\begin{array}{c}0 \\
0 \%\end{array}$ & $\begin{array}{c}0 \\
0 \%\end{array}$ & $\begin{array}{c}0 \\
0 \%\end{array}$ \\
\hline $\begin{array}{l}\text { I use information } \\
\text { sources in terms of the } \\
\text { novelty and accuracy } \\
\text { of the information } \\
\text { sources }\end{array}$ & $\begin{array}{c}18 \\
60 \%\end{array}$ & $\begin{array}{c}11 \\
36.7 \%\end{array}$ & $\begin{array}{c}0 \\
0 \%\end{array}$ & $\begin{array}{c}1 \\
3.3 \%\end{array}$ & $\begin{array}{c}0 \\
0 \%\end{array}$ \\
\hline
\end{tabular}

Table 4 describes related most of the respondents somewhat disagree about I determine the source of the information I am looking for related to the topic I am looking for $19(63.3 \%)$, I use internet sources to find information $19(63.3 \%)$ and I use to print and digital media from various available sources $18(60 \%)$. The majority of respondents $11(36.7 \%)$ somewhat agree about I use information sources in terms of the novelty and accuracy of the information sources.

\subsubsection{Location and Access to Information}

Table 5. Location and access to information

\begin{tabular}{|c|c|c|c|c|c|}
\hline Question & 1 & 2 & 3 & 4 & 5 \\
\hline I define the steps & 11 & 14 & 3 & 2 & 0 \\
\hline $\begin{array}{l}\text { used to find the } \\
\text { information I need }\end{array}$ & $36.7 \%$ & $46.7 \%$ & $10 \%$ & $6.7 \%$ & $0 \%$ \\
\hline I search & 9 & 14 & 6 & 1 & 0 \\
\hline $\begin{array}{l}\text { independently on } \\
\text { the information I } \\
\text { need }\end{array}$ & $30 \%$ & $46.7 \%$ & $20 \%$ & $3.3 \%$ & $0 \%$ \\
\hline I use more than one & 20 & 9 & 1 & 0 & 0 \\
\hline $\begin{array}{l}\text { source of } \\
\text { information to find } \\
\text { the information I } \\
\text { need }\end{array}$ & $66.7 \%$ & $30 \%$ & $3.3 \%$ & $0 \%$ & $0 \%$ \\
\hline I can easily find the & 9 & 15 & 4 & 2 & 0 \\
\hline information I need & $30 \%$ & $50 \%$ & $13.3 \%$ & $6.7 \%$ & $0 \%$ \\
\hline
\end{tabular}


Table 5 describes related most of the respondents somewhat disagree about I define the steps used to find the information I need 14 (46.7\%), I search independently on the information I need 14 (46.7\%), and I can easily find the information I need 15 (50\%). The majority of respondents $20(66.7 \%)$ somewhat agree about I use more than one source of information to find the information I need.

\subsubsection{Information Usage}

Table 6. Information usage

\begin{tabular}{lccccc}
\hline \multicolumn{1}{c}{ Question } & $\mathbf{1}$ & $\mathbf{2}$ & $\mathbf{3}$ & $\mathbf{4}$ & $\mathbf{5}$ \\
\hline $\begin{array}{l}\text { I use the I use } \\
\text { information to solve }\end{array}$ & $53.3 \%$ & $46.7 \%$ & $0 \%$ & $0 \%$ & $0 \%$ \\
problems & & & & & \\
$\begin{array}{l}\text { I combine some of } \\
\text { the information I }\end{array}$ & 18 & 11 & 3.3 & 0 & 0 \\
found before I used & & $36.7 \%$ & $0 \%$ & $0 \%$ & $0 \%$ \\
it using & 17 & 12 & 1 & 0 & 0 \\
$\begin{array}{l}\text { Before I } \\
\text { information, }\end{array}$ & & & & & \\
interpret \\
(interpretation) the
\end{tabular}

Table 6 describes related most of the respondents strongly agree that I use the information to solve problems $16(53.3 \%)$, I combine some of the information I found before I used it $18(60 \%)$ and before using the information I interpret (interpretation) the information $17(56.7 \%)$. Most of the respondents somewhat disagree about I effectively communicate the results of the information I find to others 10 (33.3\%).

\subsubsection{Synthesis: Information Organization}

Table 7. Synthesis: information organization

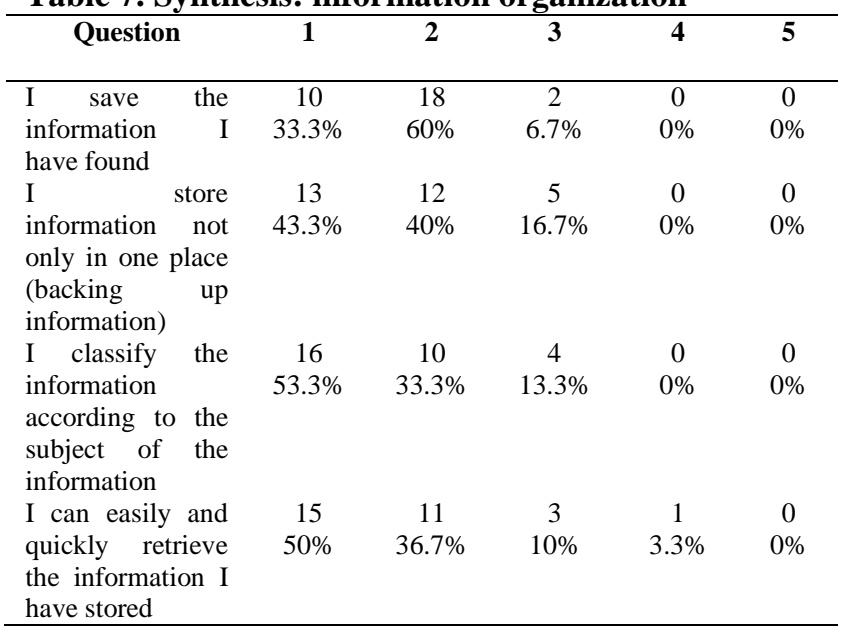

Table 7 describes related the majority of respondents somewhat agree about I store information not only in one place (backing up information) 13 (43.3\%), I classify the information according to the subject of the information $16(53.3 \%)$, and I can easily and quickly retrieve the information I have stored 15 $(50 \%)$. Most of the respondents somewhat disagree about I save the information I have found 18 (60\%).

\subsubsection{Evaluation:Judge the Result (Effectiveness) and Process (Efficiency)}

Table 8. Evaluation

\begin{tabular}{lccccc}
\hline \multicolumn{1}{c}{ Question } & $\mathbf{1}$ & $\mathbf{2}$ & $\mathbf{3}$ & $\mathbf{4}$ & $\mathbf{5}$ \\
\hline $\begin{array}{l}\text { I assessed the } \\
\text { various }\end{array}$ & 13 & 15 & 0 & 2 & 0 \\
information that I & $43.3 \%$ & $50 \%$ & $0 \%$ & $6.7 \%$ & $0 \%$ \\
had found & & & & & \\
$\begin{array}{l}\text { I evaluate various } \\
\text { information that I }\end{array}$ & 16 & 11 & 1 & 2 & 0 \\
$\begin{array}{l}\text { have found any } \\
\text { I review if there } \\
\text { are }\end{array}$ & $930 \%$ & $36.7 \%$ & $3.3 \%$ & $6.7 \%$ & $0 \%$ \\
deficiencies in the \\
results I conclude \\
and discuss them
\end{tabular}

Table 8 describes related most of the respondents somewhat disagree about I assessed the various information that I had found 15 (50\%), I review if there are any deficiencies in the results I conclude and discuss them again with experts and compare with related theories $17(56.7 \%)$ and I reevaluated from the process of finding information to concluding $20(66.7 \%)$. The majority of respondents $16(53.3 \%)$ somewhat agree about I evaluate various information that I have found.

\subsection{Status of Indigenous Knowledge}

Status indigenous knowledge is a network of knowledge, beliefs, and traditions aimed at preserving, communicating, and contextualizing indigenous cultural and landscape relationships over time. To see the status of indigenous knowledge, it is done by following four basic patterns: (1) intangible to intangible (socializing) where individuals exchange intangible knowledge through personal communication, (2) intangible to tangible (externalization) - where the codification of understanding, perspective, and opinion broadens the basic knowledge, (3) tangible to tangible (combination) - where people combine other people's tangible knowledge to create a new whole, and (4) tangible to intangible (internalization) - where people use other people's codified knowledge to enhance intangible knowledge. 


\subsubsection{Socialization}

Socialization is the transfer of knowledge from one individual to another in the form of tacit knowledge.

\section{Table 9. Socialization}

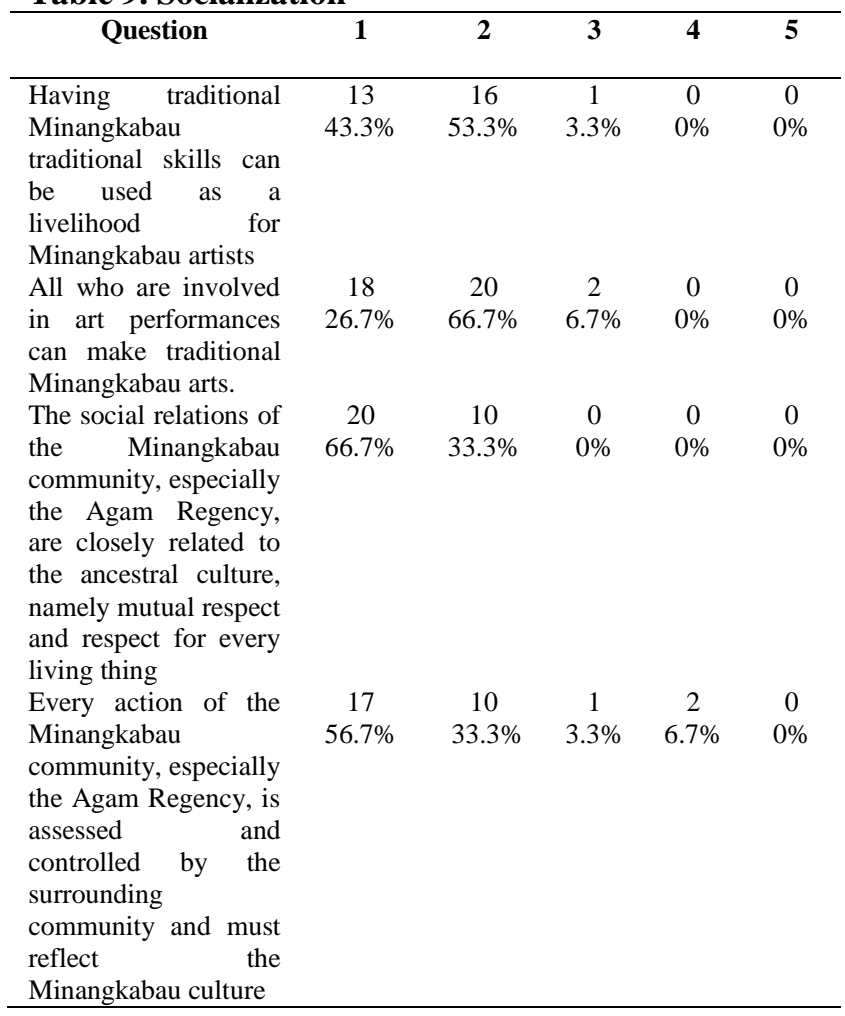

Table 9 describes related most of the respondents somewhat disagree about having traditional Minangkabau traditional skills can be used as a livelihood for Minangkabau artists 16 (53.3\%), and all who are involved in art performances can make traditional Minangkabau arts. $20(66.7 \%)$ The majority of respondents somewhat agree about The social relations of the Minangkabau community, especially the Agam Regency, are closely related to the ancestral culture, namely mutual respect and respect for every living thing $20(66.7 \%)$ and Every action of the Minangkabau community, especially the Agam Regency, is assessed and controlled by the surrounding community and must reflect the Minangkabau culture $17(56.7 \%)$.

\subsubsection{Externalization}

Externalization is the process of transforming knowledge from the tacit form to the explicit form (tacit knowledge that exists within the individual is issued and formulated into other media that can be easily learned by other individuals).
Table 10. Externalization

\begin{tabular}{|c|c|c|c|c|c|}
\hline Question & 1 & 2 & 3 & 4 & 5 \\
\hline $\begin{array}{l}\text { Documenting } \\
\text { indigenous knowledge } \\
\text { Minangkabau is a } \\
\text { cultural heritage that } \\
\text { exists in the } \\
\text { community, which is } \\
\text { carried out from } \\
\text { generation to } \\
\text { generation by the } \\
\text { community concerned }\end{array}$ & $\begin{array}{c}16 \\
53.3 \%\end{array}$ & $\begin{array}{c}13 \\
43.3 \%\end{array}$ & $\begin{array}{c}1 \\
3.3 \%\end{array}$ & $\begin{array}{c}0 \\
0 \%\end{array}$ & $\begin{array}{c}0 \\
0 \%\end{array}$ \\
\hline $\begin{array}{l}\text { Write down the } \\
\text { knowledge and } \\
\text { experience gained in } \\
\text { the form of written } \\
\text { articles or material } \\
\text { from books }\end{array}$ & $\begin{array}{c}9 \\
30 \%\end{array}$ & $\begin{array}{c}13 \\
43.3 \%\end{array}$ & $\begin{array}{c}7 \\
23.3 \\
\%\end{array}$ & $\begin{array}{c}1 \\
3.3 \%\end{array}$ & $\begin{array}{c}0 \\
0 \%\end{array}$ \\
\hline $\begin{array}{l}\text { The traditional } \\
\text { Minangkabau } \\
\text { performing arts } \\
\text { function as guides and } \\
\text { moral messengers for } \\
\text { the owner society } \\
\text { which is presented in } \\
\text { the dialogues and } \\
\text { stories presented }\end{array}$ & $\begin{array}{c}17 \\
56.7 \%\end{array}$ & $\begin{array}{c}12 \\
40 \%\end{array}$ & $\begin{array}{c}1 \\
3.3 \%\end{array}$ & $\begin{array}{c}0 \\
0 \%\end{array}$ & $\begin{array}{c}0 \\
0 \%\end{array}$ \\
\hline $\begin{array}{l}\text { Reports on indigenous } \\
\text { knowledge based on } \\
\text { the experiences } \\
\text { collected }\end{array}$ & $\begin{array}{c}8 \\
26.7 \%\end{array}$ & $\begin{array}{c}17 \\
56.7 \%\end{array}$ & $\begin{array}{c}3 \\
10 \%\end{array}$ & $\begin{array}{c}1 \\
3.3 \%\end{array}$ & $\begin{array}{c}1 \\
3.3 \%\end{array}$ \\
\hline
\end{tabular}

Table 10 describes related the majority of respondents somewhat agree about Documenting indigenous knowledge Minangkabau is a cultural heritage that exists in the community, which is carried out from generation to generation by the community concerned $16(53.3 \%)$, and the traditional Minangkabau performing arts function as guides and moral messengers for the owner society which is presented in the dialogues and stories presented 17 (56.7\%). Most of the respondents somewhat disagree about Write down the knowledge and experience gained in the form of written articles or material from books $13(43.3 \%)$, and Reports on indigenous knowledge based on the experiences collected 17 (56.7\%).

\subsubsection{Combination}

The combination is organizing a collection of explicit knowledge into a form of media that is more systematic, through the process of adding new knowledge, combination, and categorization of knowledge that has been collected. 
Table 11. Combination

\begin{tabular}{|c|c|c|c|c|c|}
\hline Question & 1 & 2 & 3 & 4 & 5 \\
\hline $\begin{array}{l}\text { Mingakabau } \\
\text { traditional art } \\
\text { functions as an } \\
\text { educational medium, } \\
\text { which is reflected in } \\
\text { the natural philosophy } \\
\text { of the life of "Alam } \\
\text { Takambang Jadi }\end{array}$ & $\begin{array}{c}16 \\
53.3 \%\end{array}$ & $\begin{array}{c}14 \\
46.7 \%\end{array}$ & $\begin{array}{c}0 \\
0 \%\end{array}$ & $\begin{array}{c}0 \\
0 \%\end{array}$ & $\begin{array}{c}0 \\
0 \%\end{array}$ \\
\hline Guru" as a way of life & & & & & \\
\hline $\begin{array}{lr}\text { Transfer } & \text { of } \\
\text { knowledge } & \text { and } \\
\text { experience is carried } \\
\text { out through formal } \\
\text { and informal } \\
\text { discussions }\end{array}$ & $\begin{array}{c}13 \\
43.3 \%\end{array}$ & $\begin{array}{c}15 \\
50 \%\end{array}$ & $\begin{array}{c}2 \\
6.7 \%\end{array}$ & $\begin{array}{c}0 \\
0 \%\end{array}$ & $\begin{array}{c}0 \\
0 \%\end{array}$ \\
\hline $\begin{array}{l}\text { Get used to learning } \\
\text { from reading books, } \\
\text { news, and documents } \\
\text { indigenous knowledge }\end{array}$ & $\begin{array}{c}13 \\
43.3 \%\end{array}$ & $\begin{array}{c}16 \\
53.3 \%\end{array}$ & $\begin{array}{c}1 \\
3.3 \%\end{array}$ & $\begin{array}{c}0 \\
0 \%\end{array}$ & $\begin{array}{c}0 \\
0 \%\end{array}$ \\
\hline $\begin{array}{l}\text { Familiarize oneself } \\
\text { with providing } \\
\text { assistance and advice } \\
\text { in solving problems } \\
\text { through Indigenous } \\
\text { knowledge }\end{array}$ & $\begin{array}{c}13 \\
43.3 \%\end{array}$ & $\begin{array}{c}16 \\
53.3 \%\end{array}$ & $\begin{array}{c}0 \\
0 \%\end{array}$ & $\begin{array}{c}1 \\
3.3 \%\end{array}$ & $\begin{array}{c}0 \\
0 \%\end{array}$ \\
\hline
\end{tabular}

Table 11 describes related most of the respondents strongly agree that Mingakabau traditional art functions as an educational medium, which is reflected in the natural philosophy of the life of "Alam Takambang Jadi guru" as a way of life $16(53.3 \%)$. Most of the respondents somewhat disagree about Transfer of knowledge and experience is carried out through formal and informal discussions 15 (50\%), Get used to learning from reading books, news, and documents indigenous knowledge $16(53.3 \%)$, and familiarize oneself with providing assistance and advice in solving problems through Indigenous knowledge 16 (53.3\%).

\subsubsection{Internalization}

Internalization is the process of transforming knowledge from an explicit form to a tacit form.

Table 12. Internalization

\begin{tabular}{|c|c|c|c|c|c|}
\hline Question & 1 & 2 & 3 & 4 & 5 \\
\hline $\begin{array}{lr}\text { Access results } & \text { from } \\
\text { seminars, roadshows, } \\
\text { workshops, training } \\
\text { programs, } \\
\text { conferences }\end{array}$ & $\begin{array}{c}8 \\
26.7 \%\end{array}$ & $\begin{array}{c}20 \\
66.7 \%\end{array}$ & $\begin{array}{c}1 \\
3.3 \%\end{array}$ & $\begin{array}{c}1 \\
3.3 \%\end{array}$ & $\begin{array}{c}0 \\
0 \%\end{array}$ \\
\hline $\begin{array}{l}\text { Manage indigenous } \\
\text { knowledge training } \\
\text { programs (have done } \\
\text { knowledge sharing) }\end{array}$ & $\begin{array}{c}8 \\
26.7 \%\end{array}$ & $\begin{array}{c}16 \\
53.3 \%\end{array}$ & $\begin{array}{c}3 \\
10 \%\end{array}$ & $\begin{array}{c}3 \\
10 \%\end{array}$ & $\begin{array}{c}0 \\
0 \%\end{array}$ \\
\hline $\begin{array}{l}\text { Encouraging activities } \\
\text { of indigenous } \\
\text { knowledge in the } \\
\text { community }\end{array}$ & $\begin{array}{c}14 \\
46.7 \%\end{array}$ & $\begin{array}{c}15 \\
50 \%\end{array}$ & $\begin{array}{c}1 \\
3.3 \%\end{array}$ & $\begin{array}{c}0 \\
0 \%\end{array}$ & $\begin{array}{c}0 \\
0 \%\end{array}$ \\
\hline $\begin{array}{l}\text { Arrange meetings, } \\
\text { seminars, roadshows, or } \\
\text { conferences (exchange of } \\
\text { indigenous knowledge } \\
\text { through formal or } \\
\text { informal meetings) }\end{array}$ & $\begin{array}{c}10 \\
33.3 \%\end{array}$ & $\begin{array}{c}14 \\
46.7 \%\end{array}$ & $\begin{array}{c}3 \\
10 \%\end{array}$ & $\begin{array}{c}3 \\
10 \%\end{array}$ & $\begin{array}{c}0 \\
0 \%\end{array}$ \\
\hline
\end{tabular}

Table 12 describes related most of the respondents somewhat disagree about access results from seminars, roadshows, workshops, training programs, or conferences $20(66.7 \%)$, manage indigenous knowledge training programs (have done knowledge sharing) 16 $(53.3 \%)$, encouraging activities of indigenous knowledge in the community $15(50 \%)$, and arrange meetings, seminars, roadshows, or conferences (exchange of indigenous knowledge through formal or informal meetings) 14 (46.7).

\section{CONCLUSION}

Based on the results of the research analysis, a conclusion can be drawn as follows: (1) Information literacy is a set of abilities and knowledge that a person has to know when information is needed and the ability to locate, evaluate, and use effectively information needs, and (2) Regarding the status of indigenous knowledge of the Minangkabau community, almost all respondents agree that the activity is carried out through four stages, namely (a) socialization which is the transfer of knowledge from one individual to another in the form of tacit knowledge, (b) transformation of knowledge from tacit form to explicit form where tacit knowledge that exists within the individual is removed and formulated into other media that can be easily learned by other individuals, (c) the combination is done by organizing a collection of explicit knowledge into a more systematic form of media, through the process of adding new knowledge, combining and categorizing knowledge. That has been collected, and (4) internalization is the process of transforming knowledge from explicit form to tacit form.

\section{AUTHORS' CONTRIBUTIONS}

ER wrote the original manuscript and contributed to conceptualization, introduction, investigation, methodology, and formal analysis. SMS supervised the research work and contributed to methodology, reviewing, and editing. WAWY supervised, reviewed, and edited the research work.

\section{ACKNOWLEDGMENTS}

The authors express their sincere thanks to everyone who contributed their ideas and thoughts to this research through participation in the survey and, in particular, to the thirty people who volunteered their time to answer the questions in the questionnaire. Thanks to Faculty of Information Management, Universiti Teknologi MARA, Malaysia and Universitas Negeri Padang, Padang, Sumatera Barat, Indonesia. 


\section{REFERENCES}

[1] S. Ronra Shimray and C. Kodand Ramaiah, "Factors of influence on sharing of cultural heritage knowledge," VINE J. Inf. Knowl. Manag. Syst., no. September, 2020, doi: 10.1108/VJIKMS-04-2020-0074.

[2] L. Setiyowati, S. Pascasarjana, and U. P. Indonesia, "Konsep Indegenous Environmental Knowledge Dalam Meningkatkan Literasi Masyarakat Desa Ngantru Kabupaten Bojonegoro," J. Pendidik. Luar Sekol., vol. 13, no. 2, pp. 1-8, 2017.

[3] D. Mulyono and A. Ansori, "Literasi Informasi Dalam Kerangka Pengembangan Pendidikan Masyarakat," Comm-Edu (Community Educ. Journal), vol. 3, no. 1, p. 1, 2020, doi: 10.22460/comm-edu.v3i1.3516.

[4] A. Bundy, "Australian and New Zealand Information Literacy Framework," Princ. Stand. Pract., vol. 2, p. 48, 2004.

[5] M. S, "Relevance of Information Literacy in Digital Environment," J. Inf. Technol. Rev., vol. 10, no. 2, p. 48, 2019, doi: $10.6025 / \mathrm{jitr} / 2019 / 10 / 2 / 48-52$.

[6] P. A. Kerr, "Conceptions and Practice of Information Literacy,” 2010.

[7] H. Partridge, C. Bruce, and C. Tilley, "Community information literacy: Developing an Australian research agenda," Libri, vol. 58, no. 2, pp. 110-122, 2008, doi: 10.1515/libr.2008.013.

[8] T. Koltay, "The media and the literacies: Media literacy, information literacy, digital literacy," Media, Cult. Soc., vol. 33, no. 2, pp. 211-221, 2011, doi: $10.1177 / 0163443710393382$.

[9] I. R. Maruf, "The Protection of Indonesian Indigenous Heritage in the International Conventions and Their Implication toward Indonesian Law," J. Sampurasun Interdiscip. Stud. Cult. Herit., vol. 1, no. 1, 2015, doi: 10.23969/sampurasun.v1i1.17.
[10] C. L. Liew, "Towards dynamic and evolving digital libraries," Electron. Libr., vol. 32, no. 1, pp. 2-16, 2014, doi: 10.1108/EL-07-2012-0089.

[11] J. K. Sarkhel, "Strategies of Indigenous Knowledge Management in Libraries," Qual. Quant. Methods Libr., vol. 5, pp. 427-439, 2016.

[12] D. T. Kurnilasari, A. Yahanan, and R. A. Rahim, "Indonesia's Traditional Knowledge Documentation in Intellectual Property Rights' Perspective," Sriwij. Law Rev., vol. 2, no. 1, p. 110, 2018, doi: 10.28946/slrev.vol2.iss1.114.pp110-130.

[13] L. Hakim and P. D. Negara, "Perlindungan Pengetahuan Tradisional (Traditional Knowledge) Dalam Dimensi HAM: Upaya Harmonisasi Hukum Dalam Kerangka Pembangunan Hukum Di Indonesia," Proceeding Conf. Innov. Appl. Sci. Technol., no. September, pp. 318-327, 2018.

[14] J. . Creswell, Research Design: Pendekatan Kualitatif, Kuantitatif dan mixed. 2009. 